Biomass and essential oil yields of cornmint (Mentha arvensis L.) grown in the irrigation area of Río Dulce, Santiago del Estero, Argentina

Diego A. Meloni' , Maria Paz Arraiza , Fernando Garay , Diolina Moura Silva , Gabriela Abdala , Renée Noelia David , Jose Vicente Lopez \& Rosa Elisabeth Beltrar. 


\title{
Biomass and essential oil yields of cornmint (Mentha arvensis L.) grown in the irrigation area of Río Dulce, Santiago del Estero, Argentina
}

\author{
Diego A. Meloni , Maria Paz Arraiza , Fernando Garay, Diolina Moura Silvá, Gabriela Abdala , \\ Renée Noelia David, Jose Vicente Lopez and Rosa Elisabeth Beltran
}

\begin{abstract}
The aim of this study is to determine the yield and composition of the essential oil of cornmint (Mentha arvensis L.) grown in the irrigation area of Santiago del Estero, Argentina. Field tests were carried out under irrigation conditions, harvesting when $70 \%$ flowering was reached (in the summer and at the end of the winter seasons). Essential oil yields were $2 \%$ in the first cut and $1.6 \%$ in the second cut, respectively, the major constituents of the essential oil being menthol, menthone, isomenthone and menthofuran. In both cases, a high concentration of menthol was obtained, although during the winter the content decreased, increasing the concentration of menthofuran. It is concluded that during the summer a higher yield and better quality of essential oil are produced.
\end{abstract}

\section{Introduction}

The world market for spices is booming, with the USA, Germany and Japan the largest importers (1). Among spices, mint stands out, from which leaves and essential oils are commercialized. It is expected to expand its cultivation in a wide geographic region in Argentina, since the demand for fresh product, as well as its essential oil, is increasing (2).

The generic name of Mentha is used for several species of the family Lamiaceae. Among the naturalized mint in America is Mentha arvensis L. (cornmint), a perennial herbaceous plant vegetatively propagated by stolons (3). It can reach a height of about $40 \mathrm{~cm}$ and it is mainly used for the production of essential oil, from which menthol is extracted. Menthol has multiple applications: in liquors, toothpaste, nasal drops, perfume and cosmetics, among others (4). It is one of the favorite flavors in the world market, along with vanilla, citrus and chocolate. India and China are the main producers of essential oils of peppermint, menthol, mint terpenes and dementholized oil (5).

The cultivation of cornmint has significant potential in the Río Dulce irrigation area, in the province of Santiago del Estero, Argentina, where the environmental conditions are optimal for its development (6). These conditions not only promote growth, but would be optimal for the production of an essential oil of excellent quality. In this sense, several studies show that high temperatures and long photoperiods, such as those that characterize the province of Santiago del Estero, increase the production of essential oil and the percentage of menthol $(7,8)$. Although exploratory tests were previously conducted, there are no reports on the performance of the species in the region or the composition of its essential oil. The aim of this study is to determine the yield and composition of the essential oil of cornmint grown in the irrigation area of Santiago del Estero, Argentina.

\section{Materials and methods}

The climate of the region is characterized as subtropical with a dry season, featuring in the late winter and early part of spring. During this season, there are dominant hot dry winds from the north sector, producing a great effect of evaporation, which increases the dryness of the air (9). The average rainfall is 550 $\mathrm{mm}$ per year, and the average maximum temperature $45^{\circ} \mathrm{C}$; the rapid rise in temperature in the spring, combined with the limited availability of soil water and the wind, result in an increased air saturation deficit (9). Table 1 shows the agro-metheorological variables during the period when the test was conducted. 
Table 1. Values of maximum, minimum, average temperatures, precipitations and photoperiod for the duration of the trial. ${ }^{\text {a }}$

\begin{tabular}{lccccc}
\hline Month & Max. temp. $\left({ }^{\circ} \mathrm{C}\right)$ & Min. temp. $\left({ }^{\circ} \mathrm{C}\right)$ & Av. temp $\left({ }^{\circ} \mathrm{C}\right)$ & Precipitation (mm) & Photoperiod (hours) \\
\hline April 2009 & 35.1 & 10.7 & 21.7 & 9.2 & 12.1 \\
May & 31.5 & 2.6 & 16.9 & 3.6 & 11.3 \\
June & 14.3 & -2.7 & 11.9 & 0 & 11.2 \\
July & 31.3 & -5.4 & 10.3 & 0.6 & 11.4 \\
August & 38.1 & -3.1 & 16.3 & 0.6 & 11.8 \\
September & 33.9 & -2.3 & 16.1 & 3 & 12.7 \\
October & 39.1 & 2.6 & 23.1 & 69.8 & 13.6 \\
November & 44.6 & 13.8 & 27.2 & 129.2 & 14.4 \\
December & 37.5 & 14.7 & 25.9 & 106.2 & 14.8 \\
Jan. 2010 & 38.9 & 13.1 & 25.7 & 96.6 & 14.6 \\
February & 40.8 & 14.7 & 26.2 & 70.8 & 13.8 \\
March & 34.8 & 14.5 & 24.8 & 18.2 & 13.0 \\
April & 34.4 & 4.0 & & \\
\hline
\end{tabular}

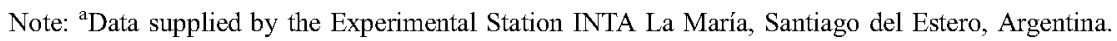

\subsection{Plant material}

The crop was introduced on April 4, 2009, in the municipality of Villa Zanjón $\left(27^{\circ} 45^{\prime} \mathrm{S}, 64^{\circ} 18^{\prime} \mathrm{W}\right)$, Santiago del Estero, Argentina, under irrigation. Irrigations were performed on June 19, August 4, October 8, 2009 and February 6, 2010. Irrigation was performed using the technique of flooding, which is the most commonly used by farmers in the region, with a water layer of 130 $\mathrm{mm}$. Regular monitoring of the phenology of the test was carried out, and when it reached 70\% flowering, plants were harvested by hand at a height of $10 \mathrm{~cm}$, in order to simulate a commercial cut. The experimental unit consisted of plots of $36 \mathrm{~m}^{2}$, containing twenty tacks spaced at $0.60 \mathrm{~m}$. The experimental design was a randomized block with six replications, so the total area of the test was $216 \mathrm{~m}^{2}$. The results were analyzed with analysis of variance (ANOVA) and Tukey test.

\subsection{Distillation}

Samples were weighed and then dried in an oven with forced ventilation at $35^{\circ} \mathrm{C}$ to a constant weight, to determine the biomass production and partition (10). Other samples were dried at room temperature (30$35^{\circ} \mathrm{C}$ ) to a constant weight, following the practice of local producers, and the total aerial part was ground for the extraction of essential oils. Essential oils were extracted by steam distillation using a 2-L Clevengertype apparatus at $60^{\circ} \mathrm{C}$, for 2.5 hours (11), and subsequent chemical analysis were made by gas chromatography (GC) and mass spectrometry (MS). The oils were recovered directly and were stored with anhydrous $\mathrm{Na}_{2} \mathrm{SO}_{4}$ in dark vials at $4^{\circ} \mathrm{C}$.

\section{$2.3 \mathrm{GC} / \mathrm{MS}$}

GC/flame ionization detection (GC/FID) analysis was carried out using a PerkinElmer Claus 500 GC equipped with $30 \mathrm{~m} \times 0.32 \mathrm{~mm}$ Elite-5MS capillary columns $(0.32 \mu \mathrm{m}$ film thickness $) ; 1 \mu \mathrm{L}$ of each sample was diluted with $300 \mu \mathrm{L}$ of $\mathrm{Et}_{2} \mathrm{O}$ and injected $(0.5 \mu \mathrm{l})$ with a column temperature program of $40^{\circ} \mathrm{C}$ for $5 \mathrm{~min}$ utes, increased to $280^{\circ} \mathrm{C}$ at $4^{\circ} \mathrm{C} /$ minute and finally held at this last temperature for 10 minutes. Injector and detector were set at $250^{\circ}$ and $300^{\circ} \mathrm{C}$, respectively, and the carrier gas was $\mathrm{He}$ with a head pressure of 12.0 psi. GC-MS analyses were carried out using a PerkinElmer Clarus 500 GC equipped with a Clarus $500 \mathrm{MS}$ using the same capillary column and chromatographic conditions as for the GC/FID analysis. Mass spectra were acquired over the $40-500 \mathrm{amu}$ range at $1 \mathrm{scan} /$ second with an ionizing electron energy of $70 \mathrm{eV}$, ion source $200^{\circ} \mathrm{C}$. The transfer line was set at $300^{\circ} \mathrm{C}$, carrier gas has $\mathrm{He}$ at $1.0 \mathrm{~mL} /$ minute. The identification of the oil components was performed by their linear retention indices (LRI), authentic reference compounds, peak matching library search and published mass spectra $(12,13)$. LRIs were calculated using an $n$-alkane series $\left(\mathrm{C}_{6}-\mathrm{C}_{32}\right)$ under the same $\mathrm{GC}$ conditions as for the samples.

\subsection{Chemicals}

All compounds were analytical standard grade. Anhydrous $\mathrm{Na}_{2} \mathrm{SO}_{4}$ was analytical reagent grade.

\section{Results and discussion}

There were two flowerings during the growing season, cuts were performed on January 4 (summer) and September 4, 2010 (winter) (275 and 360 days after crop establishment), with a fresh biomass production of 15.41 and $15.66 \mathrm{t} / \mathrm{ha}$, respectively (5.9 and $5.5 \mathrm{t} / \mathrm{ha}$ dry biomass). The total yield of $31.07 \mathrm{t} / \mathrm{ha}$ coincides with that mentioned by other authors, which is in the range 20-30 t/ha (14). Although there were no significant 


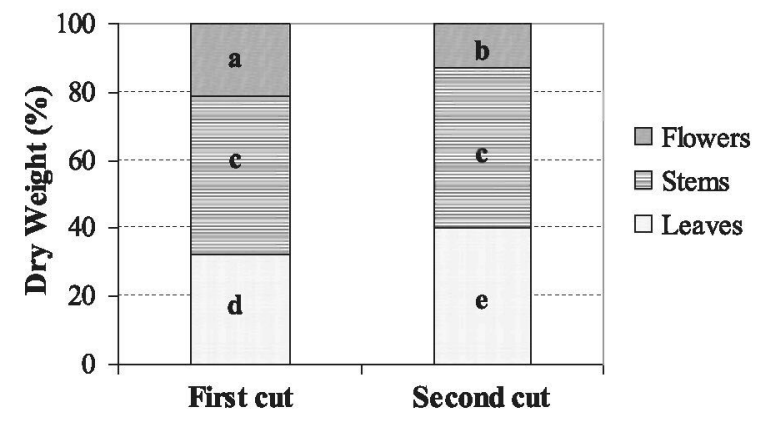

Figure 1. Dry weight percentage of leaves, stems and flowers.

differences in the performance of both crops, they differed in their dry matter partition; in the second cutm a decrease in the dry matter percentage of flowers appeared, along with an increase in the dry matter percentage of leaves relative to the first cut (Figure 1).

The essential oil yield was $2.0 \%$ in the first cut and $1.6 \%$ in the second.

The chemical composition of essential oils was within the standards required by the Pharmacopoeia (Table 2), which sets a content of menthol greater than $50 \%$, and that of menthyl acetate between $5 \%$ and $20 \%$ (15).

The menthol content in both cuts was similar to that given in other references. Murray et al. (16) reported $64-73 \%$ menthol in 1970 in Indiana $\left(41^{\circ} 39^{\prime} \mathrm{N}\right.$ lat.) and $48-58 \%$ in 1972 in Michigan $\left(42^{\circ} 36^{\prime} \mathrm{N}\right.$ lat.). Zheljazkov and Margina (17) reported 61-67\% menthol in a cultivar of $M$. arvensis, and Zheljazkov et al. (18) obtained $57-64 \%$ of menthol in two cultivars of $M$. arvensis in Plovdiv, Bulgaria $\left(42^{\circ} 08^{\prime} \mathrm{N}\right.$ lat.). Pandey et al. (19) reported $71 \%$ menthol in crops grown in central India. Zheljazkov et al. (10) reported a yield of menthol ranging between $67 \%$ and $78 \%$ in cultivars of cornmint, from trials conducted in the area of Mississippi, USA.

The isoprenoid biosynthetic pathway leads to the formation of geranyl pyrophosphate, from which limonene is originated, and then piperitone and pulegone; pulegone is an immediate precursor of the menthone and menthofuran. From menthone, neomenthol and menthol are synthesized, and menthol becomes menthyl acetate by esterification (20).

Agronomic and environmental factors that lead to the conversion of menthone to menthol are desirable, opposite to those promoting the synthesis of menthofuran. In this study we found a significant decrease in the percentage of menthol and menthyl acetate in the second harvest, coinciding with the presence of $6.3 \%$ of menthofuran, which was absent in the essential oil from the first cut. This response may be due to two factors.

According to Piccaglia et al. (21), as species of the genus Mentha require long photoperiods, the decline in the number of hours of light induces the formation of

Table 2. Chemical composition (\%) of essential oil of cornmint (Mentha arvensis L.)

\begin{tabular}{|c|c|c|c|c|}
\hline Compound & LRI ref. ${ }^{1}$ & LRI exp. ${ }^{2}$ & First cut & Second cut \\
\hline$\alpha$-Thujene & 932 & 928 & $\operatorname{tr}$ & $\operatorname{tr}$ \\
\hline$\alpha$-Pinene & 939 & 933 & $0.6[ \pm 0.1]^{\mathrm{a}}$ & $0.7[ \pm 0.2]^{\mathrm{a}}$ \\
\hline Camphene & 950 & 946 & $0.1[ \pm 0.0]^{\mathrm{a}}$ & $0.1[ \pm 0.0]^{\mathrm{a}}$ \\
\hline$\beta$-Pinene & 979 & 973 & $0.4[ \pm 0.0]^{\mathrm{a}}$ & $0.4[ \pm 0.0]^{\mathrm{a}}$ \\
\hline Myrcene & 990 & 984 & $0.9[ \pm 0.1]^{\mathrm{a}}$ & $1.1[ \pm 0.1]^{\mathrm{a}}$ \\
\hline Limonene & 1029 & 1024 & $1.2[ \pm 0.1]^{\mathrm{a}}$ & $1.1[ \pm 0.1]^{\mathrm{a}}$ \\
\hline trans-Sabinene hydrate & 1053 & 1055 & $0.1[ \pm 0.0]^{\mathrm{a}}$ & $0.1[ \pm 0.0]^{\mathrm{a}}$ \\
\hline Terpinolene & 1082 & 1087 & $\operatorname{tr}$ & tr \\
\hline Linalool & 1096 & 1100 & $0.4[ \pm 0.0]^{\mathrm{a}}$ & $0.4[ \pm 0.0]^{\mathrm{a}}$ \\
\hline Menthone & 1136 & 1141 & $11.0[ \pm 0.1]^{\mathrm{a}}$ & $6.4[ \pm 0.3]^{b}$ \\
\hline Isomenthone & 1146 & 1149 & $4.6[ \pm 0.0]^{\mathrm{a}}$ & $3.7[ \pm 0.0]^{\mathrm{b}}$ \\
\hline Menthofuran & 1150 & 1154 & $0.1[ \pm 0.0]^{\mathrm{a}}$ & $6.3[ \pm 0.2]^{\mathrm{b}}$ \\
\hline Neomenthol & 1156 & 1156 & $1.1[ \pm 0.0]^{\mathrm{a}}$ & $0.7[ \pm 0.0]^{\mathrm{b}}$ \\
\hline Menthol & 1172 & 1171 & $77.1[ \pm 0.6]^{\mathrm{a}}$ & $68.1[ \pm 0.5]^{\mathrm{b}}$ \\
\hline Pulegone & 1215 & 1215 & $1.0[ \pm 0.1]^{\mathrm{a}}$ & $0.9[ \pm 0.1]^{\mathrm{a}}$ \\
\hline Piperitone & 1226 & 1228 & $0.5[ \pm 0.0]^{\mathrm{a}}$ & $0.6[ \pm 0.0]^{\mathrm{a}}$ \\
\hline Geraniol & 1235 & 1234 & $0.6[ \pm 0.1]^{\mathrm{a}}$ & $0.5[ \pm 0.0]^{\mathrm{a}}$ \\
\hline Menthyl acetate & 1280 & 1285 & $6.0[ \pm 0.0]^{\mathrm{a}}$ & $5.0[ \pm 0.0]^{\mathrm{b}}$ \\
\hline$\beta$-Elemene & 1389 & 1386 & $0.1[ \pm 0.0]^{\mathrm{a}}$ & $0.1[ \pm 0.0]^{\mathrm{a}}$ \\
\hline$\beta$-Cariophyllene & 1419 & 1424 & $0.7[ \pm 0.0]^{\mathrm{a}}$ & $0.7[ \pm 0.1]^{\mathrm{a}}$ \\
\hline Geranyl acetate & 1430 & 1433 & $0.2[ \pm 0.0]^{\mathrm{a}}$ & $0.2[ \pm 0.0]^{\mathrm{a}}$ \\
\hline Germacrene D & 1479 & 1486 & $0.1[ \pm 0.0]^{\mathrm{a}}$ & $0.1[ \pm 0.0]^{\mathrm{a}}$ \\
\hline$\delta$-Cadinene & 1520 & 1520 & $0.2[ \pm 0.0]^{\mathrm{a}}$ & $0.2[ \pm 0.0]^{\mathrm{a}}$ \\
\hline (E)-Nerolidol & 1553 & 1548 & $0.1[ \pm 0.0]^{\mathrm{a}}$ & $0.1[ \pm 0.0]^{\mathrm{a}}$ \\
\hline
\end{tabular}

Note: tr, traces $<0.1 \%$. ${ }^{a, b}$ For each compound, values followed by different letters differ significantly by Tukey test at $5 \%$. ${ }^{1}$ Linear retention indices (LRI) reference in Wiley (23). ${ }^{2}$ LRI experimental. 
menthofuran, which justifies the decrease in the synthesis of menthol, as both compounds possess the same precursor (20). Thus, the environmental conditions in the second cut, with a photoperiod of 2.5 hours less than in the first cut, are best suited for the synthesis of menthofuran than of menthol.

Further research is needed to identify suitable agronomic factors that might reduce the concentration of menthofuran and increase the concentration of menthol. Nitrogen is one of the most important modifiers of Mentha productivity and oil composition (22). Thus, in future trials, the effect of nitrogen fertilization on yield and quality of essential oils during the winter season should be studied.Menthyl acetate levels ranged between $5.9 \%$ and $5.0 \%$ in the first and second cuts, respectively. These values are higher than the 4\% obtained by Rao (5) in Southern India. Although menthyl acetate has little economic importance, compared with menthol, it is used in perfumery, as it has floral notes, especially rose, and is used for the development of perfumes (7).

\section{Conclusions}

The high quality of essential oils obtained is given by the high percentage of menthol, menthone, isomenthone and menthyl acetate, showing the features demanded by the market, according to the references, with a menthol content higher than $50 \%$ in both harvests and menthyl acetate between $5 \%$ and $20 \%$. In the second cut, made at the end of the winter season, there was an increase in the concentration of menthofuran, and therefore, a lower quality of essential oils.

Two full cuts could be obtained from cornmint grown in the irrigation area of Santiago del Estero, Argentina, with the menthol content in both of them similar to that reported by other authors.

However, the introduction of cornmint into Argentina could provide another cash crop for northwest growers. In addition, the local production of cornmint oil could promote local value-added processing and overall improvement to the sustainability and profitability of cropping systems in northwest Argentina.

\section{Acknowledgement}

This work was funded by the Council of Scientific and Technological Research of the Universidad Nacional de Santiago del Estero, Argentina.

\section{References}

1. V.D. Zheljazkov, C.L. Cantrell and T. Astatkie, Study on Japanese cornmint in Mississippi. Agron. J., 102, 696-702 (2010).
2. O. Arizio, A. Curioni and G. Matta, Evolution of Argentine exports and imports of menthol and peppermint essential oils. Proceedings of the Third Latin American Symposium on the Production of Aromatic Plants, Medicinal and Seasoning, Catamarca, 20-23 September, p.175 (2006).

3. A.L. Bandoni, Plant resources in Latin America. Editorial of the Universidad Nacional de La Plata, La Plata, Argentina (2000).

4. A. Singh, R. Srivastava, A. Kalra, R.P. Bansal, V. Tomar, R. Bahl and S. Kumar, New practices in the cultivation of mint (Mentha arvensis) in the Indo-Gangetic plains. Exp. Agr., 39, 199-207 (2003).

5. B.R.R. Rao, Biomass and essential oil yields of cornmint (Mentha arvensis L. F. piperascens Malinvaud ex Holmes) planted in different months in semi-arid tropical climate. Ind. Crop Prod., 10, 107-133 (1999).

6. E. Spegazzini, Current situation and control the quality of aromatic and medicinal herbs. Proceedings of the Third Latin American Symposium in Production of Aromatic Plants, Medicinal and Seasoning, Catamarca, 20-23 September, pp. 91-92 (2006).

7. J. Scavroni, C. Fernandez Boaro, M. Mayo Marques and L.C. Ferreira, Yield composition of essential oil of Mentha piperita L. (Lamiaceae) grown with biosolid. Braz. J. Plant. Physiol., 17, 345-351 (2005).

8. M. Berti, R. Wilckens, E. Pastene, S. Fischer and E. Guerra, Rendimiento y composición de aceite esenciales de Mentha $\times$ piperita $L$. según fuentes $y$ dosis de fertilización nitrogenada producida en la zona centro-sur de Chile. Agro-Ciencia, 24, 58-71 (2008).

9. P.E. Boletta, L.R. Acuña and M.L. Juárez de Moya, Analysis of the climatic characteristics of the province of Santiago del Estero and behavior during the dry time of the crop year 1988/1989. Convention INTA - UNSE, Santiago del Estero (1989).

10. V.D. Zheljazkov, C.L. Cantrell and T. Astakie, Yield and composition of oil from Japanese cornmint fresh and dry material harvested successively. Agron. J., 102, 1652-1656 (2010).

11. R.S. Chauhan, M.K. Kaul, A.K. Shahi, A. Kumar, G. Ram and A. Tawa, Chemical composition of essential oils in Mentha spicata L. accession [IIIM(J)26] from NorthWest Himalayan region, India. Ind. Crops Prod., 29, 654-656 (2009).

12. NIST/EPA/NIH, NIST/EPA/NIH Mass Spectral Database, version 2.1. PerkinElmer Instrument LLC (2000).

13. R.P. Adams, Identification of Essential Oil Components by Gas Chromatography/Mass Spectrometry, 4th edn. Allured Publishing Corporation, Carol Stream, IL (2007).

14. F. Muñoz, Plantas medicinales y aromáticas. Editorial Mundiprensa Libros, Madrid (2002).

15. V.E. Tyler, L. Brady and R. Robbers, Pharmacognosy, 9th edn. Lea and Febiger, Philadelphia, PA (1988).

16. M.J. Murray, W. Faas and P. Marble, Chemical composition of Mentha arvensis var piperascens and four hybrids with Mentha crispa harvested at different times in Indiana and Michigan. Crop Sci., 12, 742-745 (1972).

17. V.D. Zheljazkov and A. Margina, Effect of increasing doses of fertilizer application on quantitative and qualitative characteristics on mint. Acta Hortic., 426, 579-592 (1996).

18. V.D. Zheljazkov, B. Yankov and V. Topalov, Effect of mechanical and chemical weed control on the growth, development and productivity of Mentha piperita and $\mathrm{M}$. arvensis var: Piperascens grown for planting material. J. Essent. Oil Res., 8, 171-176 (1996). 
19. A.K. Pandey, M.K. Rai and D. Acharya, Chemical composition and antimycotic activity of the essential oils of corn mint (Mentha arvensis) and lemon grass (Cymbopogon flexuosus) against human pathogenic fungi. Pharm. Biol., 42, 421-425 (2003).

20. R. Croteau, T.P. Kutchan and N.G. Lewis, Natural products (secondary metabolities). In: Biochemistry and Molecular Biology of Plants. Edits., B.B. Buchnan, W. Gruissem and R.J. Jones, pp. 1250-1318, ASPB, Rockville, MD (2000).
21. R. Piccaglia, V. Dellacecca, M. Mariotti and E. Giovanelli, Agronomic factors affecting the yields and essential oil composition of peppermint (Mentha $\times$ piperita L.). Acta Hortic., 344, 29-40 (1993).

22. V.D. Zheljazkov and V. Cerven, Effect of nitrogen, location and harvesting stage on peppermint productivity, oil content and oil composition. HortScience, 44, 1267-1270 (2009).

23. Wiley, Wiley/NBS Mass Spectral Database, 4th edn. Electronic Publishing Division, Wiley, New York (2001). 